\title{
Serum Katalaz, Miyeloperoksidaz ve Paraoksonaz 1 Üzerine Bazı Bitki Ekstraktlarının In Vitro Etkisi
}

\section{In Vitro Effect of Some Plant Extracts on Serum Catalase, Myeloperoxidase and Paraoxonase 1}

\author{
Adnan KIRMiT $^{1}{ }^{(\mathbb{D})}$, Mesut IŞIK ${ }^{2}$
}

1 Harran Üniversitesi, Tıp Fakültesi, Tıbbi Biyokimya Anabilim Dalı, Şanlıurfa, Türkiye.
2 Harran Üniversitesi Sağlık Hizmetleri Meslek Yüksekokulu Eczane Hizmetleri Bölümü, Şanlıurfa, Türkiye.

Öz.

Amaç: Fenolik içerik bakımından zengin olan doğal bitkilerin geleneksel ve tamamlayııı tıpta tedavi amaçlı kullanılabileceği vurgusu yapılmaktadır. Bu amaçla Artemisia absinthium (pelin otu), Ferula communis (çakşır otu), Achillea millefolium (civanperçemi), Equisetum arvense (tarla atkuyruğu) ve Hypericum perforatum (sarı kantaron) su ektraktlarının paraoksanaz 1 (PON1), miyeloperoksidaz (MPO) ve katalaz (CAT) enzim aktiviteleri ile serum total anti-oksidan seviye (TAS) ve total oksidan seviye (TOS) üzerine etkileri araștııı Imıştır.

Materyal ve metod: Her bir bitkinin su ekstraktı hazırlanmış olup, bu ekstraktlar serum numunelerine belli oranda eklenerek nihai konsantrasyon $60 \mu \mathrm{g} / \mathrm{mL}$ olarak uygulanmıştır. Hazırlanan bu ekstraktların serum parametreleri üzerine etkilerini araştırmak için TAS ve TOS parametreleri Erel, MPO aktivitesi Bradley, PON1 aktivitesi Eckerson, CAT aktivitesi Goth yöntemiyle ölçülmüştür. Reaktiffer, Harran Üniversitesi Tıp Fakültesi Tıbbi Biyokimya Anabilim Dalı Laboratuvarında hazırlanmış ve analizler rutin Biyokimya Laboratuvarı otoanalizöründe (Architect C16000, Abbott) spekrofotometrik olarak çalısıılmıștr.

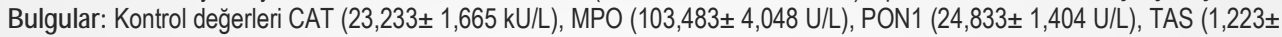
$0,080 \mathrm{mmol}$ Troloks Eqv/L) ve TOS $\left(6,350 \pm 0,481 \mu \mathrm{mol} \mathrm{H}_{2} \mathrm{O}_{2}\right.$ Eqv/L) için kantitatif olarak saptanmıştır. Pelin otu, çakşır otu, civanperçemi ve sarı kantaron CAT, MPO ve PON1 enzimlerini inhibe etmişstir $(p<0.05, p<0.01)$. Tarla atkuyruğu ise sadece MPO üzerine inhibisyon etkisi göstermiştir $(p<0.01)$. Civanperçemi ve sarı kantaron TOS düzeyini düşürürken TAS düzeyini artırmıştır $(p<0.05, p<0.01)$.

Sonuç: Çakşır otu ve tarla atkuyruğu bitki ekstraktları in vitro olarak MPO üzerine inhibisyon etkisi gösterirken PON1 üzerine ise zayıf inhibisyon etkisi göstermiştir. Bu bitkilerin in vivo etkinliği ortaya konulabilirse ateroskleroz gibi hastalıklarda intravasküler lipit peroksidasyonu sonucu meydana gelen plak oluşumunu inhibe edebileceği ve vasküler fonksiyonları iyileştirebileceği söylenebilir.

Anahtar Kelimeler: Tıbbi Bitki, Lipit peroksidasyonu, Paraoksanaz 1, Miyeloperoksidaz

Abstract

Background: It is emphasized that natural plants rich in phenolic content can be used in traditional and complementary medicine for therapeutic purposes. For this purpose, effects of the water extracts of Artemisia absinthium, Ferula communis, Achillea millefolium, Equisetum arvense and Hypericum perforatum on the serum total anti-oxidant (TAS) level and total oxidant level (TAS) and paraoxanase 1 (PON1), myeloperoxidase (MPO) and catalase (CAT) enzyme activities has been investigated. Material and method: The water extract of each plant was prepared, and these extracts were added to the serum samples in a certain amount and the final concentration was applied as $60 \mu \mathrm{g} / \mathrm{mL}$. TAS and TOS parameters were measured by Erel, MPO activity Bradley, PON1 activity Eckerson, CAT activity Goth method to investigate the effects of these prepared extracts on serum parameters. The reagents were prepared in Harran University Medical Faculty Medical Biochemistry Department Laboratory and analyzes were performed spectrophotometrically in the routine Biochemistry Laboratory autoanalyst (Architect C16000, Abbott).

Results: Control values for CAT (23,233 $\pm 1,665 \mathrm{kU} / \mathrm{L})$, MPO (103,483 $\pm 4,048 \mathrm{U} / \mathrm{L})$, PON1 $(24,833 \pm 1,404 \mathrm{U} / \mathrm{L})$, TAS $(1,223$ $\pm 0.080 \mathrm{mmol}$ Trolox Eqv/L) and TOS $\left(6.350 \pm 0,481 \mu \mathrm{mol} \mathrm{H}_{2} \mathrm{O}_{2}\right.$ Eqv/L) was detected quantitatively. Artemisia absinthium, Ferula communis, Achillea millefolium and Hypericum perforatum inhibited CAT, MPO and PON1 enzymes $(p<0.05, p<0.01)$. Equisetum arvense only showed an inhibition effect on MPO $(p<0.01)$. Achillea millefolium and Hypericum perforatum decreased the TOS level, while increasing the TAS level $(p<0.05, p<0.01)$.

Conclusion: Ferula communis and Equisetum arvense plant extracts showed an inhibition effect on MPO activity in vitro, while a weak inhibition effect on PON1 activity. If the in vivo efficacy of these plants can be demonstrated, it can be said that in diseases such as atherosclerosis, it can inhibit plaque formation caused by intravascular lipid peroxidation and improve vascular functions.

Key words: Medicinal Plant, Lipid peroxidation, Paraoxonase 1, Myeloperoxidase

\section{Sorumlu Yazar I \\ Corresponding Author}

\section{Dr. Adnan KIRMiT}

Harran Üniversitesi, Tıp Fakültesi, Tıbbi Biyokimya Anabilim Dalı, 63290 , Şanlıurfa, Türkiye. e- mail: drdemir02@gmail.com Tel: +90 4143444444 (4138) e-mail: adnankirmit@yahoo.com

Geliş tarihi / Received: 11.02.2020

Kabul tarihi / Accepted: 28.04.2020

DOI: $10.35440 /$ hutfd. 686810 


\section{Giriş}

Süperoksit anyonu, hidrojen peroksit ve hidroksil radikalleri gibi reaktif oksijen türleri (ROS) normal hücresel fonksiyon sırasında üretilir ve bu moleküllerin yüksek kimyasal reaktiviteleri lipitlerin, proteinlerin veya DNA'nın oksidasyonuna yol açar. ROS üretimi ve bunların etkisini bertaraf eden antioksidan aktivite vücutta denge halindedir. ROS üretiminin artışı veya antioksidan aktivitenin azalışı ile bu dengenin bozluması halinde oksidatif stres ortaya çıkmakta ve bu durum birçok hastalığın patogenezinde önemli bir neden teşkil etmektedir (1). Aterosklerozun, vasküler duvardaki lipit ve protein oksidasyonu ile karakterize yüksek oksidatif stres durumunu temsil ettiği konusunda bir fikir birliği bulunmaktadır. Aterosklerozun oksidatif modifikasyon hipotezi, düşük yoğunluklu lipoprotein (LDL) oksidasyonunun aterosklerozun erken safhalarında yer alan bir olay olduğunu ve okside LDL'nin aterogeneze katkıda bulunduğunu öngörmektedir (2). Serbest radikallerin lipitler, proteinler ve DNA üzerindeki oksidatif etkileri bir antioksidan spektrumu ile kontrol edilir. Antioksidanlar farklı mekanizmalar ile aterojenezi inhibe edebilir ve vasküler fonksiyonu iyileştirebilir (3-5).

Enzimatik ve enzimatik olmayan antioksidan sistemler [süperoksit dismutaz (SOD), katalaz (CAT), glutatyon peroksidaz, PON, vitamini $E, v b$. ], serbest radikallerin ve metabolik ürünlerinin atılmasının yanısıra normal hücresel fizyolojinin korunmasında, bağışıkık ve çeşitli hastalıkların önlenmesinde önemlidirler $(6,7)$.

CAT, PON1, aterosklerotik plakların ve kardiyovasküler olayların gelişimini önemli ölçüde etkileyebilecek önemli özellikleri olan hem oksidatif stres hem de inflamasyonda rol oynayan enzimlerdir (8). Aterosklerozun bir özelliği olan azalmış PON1 ve artmış MPO, HDL disfonksiyonunun önemli belirleyicileri olarak kabul edilebilir $(9,10)$.

Miyeloperoksidaz (MPO), birçok enflamatuar olay ve kardiyovasküler hastalıklarla ilişkili bir hemoproteindir (11) ve lökositler (nötrofiller gibi) tarafından büyük miktarlarda üretilir. MPO'nun birincil işlevi, hipoklorik asit (HOCl) veya hipotiyosiyanit (OSCN-) gibi reaktif oksidanların üretimidir $(12,13)$.

Serbest radikalleri giderebilen antioksidanların eksikliği, kardiyovasküler hastalıklar, kanserler (14), nörodejeneratif hastalıklar, Alzheimer hastalığı ve enflamatuar hastalıklar da dâhil olmak üzere dejeneratif hastalıkların gelişimine zemin hazırlar (15). Diyetin doğal bitki kaynaklarında bulunan antioksidan bileşiklerle desteklenmesinin bunu önlemeye yardımcı olacağı belirtilmektedir $(16,17)$. Bitkiler dünya çapında binlerce yıldır geleneksel ilaçların temeli olmuştur ve insanlığa yeni ürünler sağlamaya devam etmektedir. Koruyucu sağlık hizmetlerinin tedavi edici sağık hizmetlerine hem maliyet hem etkinlik açısından üstünlüğünün anlaşılmasıyla, birçok araştırma hastalıkları önleyici diğer tedbirlerle birlikte, birçok bitki türünün faydalı kulla- nımlarını araştırmış ve bitkilerde bulunan doğal antioksidanları tanımlamak için mevcut deneysel tekniklerin kullanılmasına odaklanmıştır $(18,19)$.

Geleneksel olarak kullanılan tıbbi bitkilerden Artemisia türleri sıtma, hepatit, kanser, iltihaplanma ve mantar, bakteri ve virüs enfeksiyonları gibi hastalıkların tedavisinde sıklıkla kullanıı ır (20). Birkaç bilimsel çalışma Ferula cinsinin terapötik olarak kullanımını ve anti-kanser, anti-diyabetik, antibakteriyel, anti-ülseratif ve anti-enflamatuar etkiler gösterdiğini kanıtlamıştır. Bu biyolojik özelliklerin temel olarak Ferula türlerinin biyoaktif metabolitler bakımından zengin olmasından kaynaklandığı söylenmektedir (21). Civanperçemi (Asteraceae), antihemorajik, iyileştirici ve analjezik özellikleri nedeniyle popüler tıpta kullanıımışırı (22). Tarla atkuyruğu geleneksel tıpta kanama, üretrit, sarılık ve hepatit tedavisinde kullanılmaktadır (23). Hypericum türleri yüzyıllardır yanıklar, çürükler, şişme, iltihaplanma ve anksiyetenin yanı sıra bakteriyel ve viral enfeksiyonların tedavisinde kullanılmaktadır (24).

Geleneksel olarak birçok hastalıkların tedavisinde kullanılan bu tıbbi bitkilerin antioksidan enzimler ile TAS ve TOS seviyesi üzerine etkilerinin bilinmesi önem arzetmektedir. Bu çalışmada yukarıda bahsedildiği gibi birçok tedavi amacıyla kullanılan bitkilerin TAS, TOS, CAT, MPO ve PON1 üzerine etkisi araştırımıştır.

\section{Materyal ve Metod}

Bu çalışmada kullanılan çakşır otu, tarla atkuyruğu Erzurum bölgesinden; pelin otu, civanperçemi ve sarı kantaron ise Adıyaman bölgesinden toplanmıştır. Gölgede kurutulduktan sonra değirmen içinde toz haline getirilen $1 \mathrm{~g}$ bitki numunesi $1 / 20$ oranında olacak şekilde suya eklendikten sonra oda koşullarında 6 saat boyunca manyetik karıştırıcı ile karıştıııldı (25). Elde edilen ekstraktlar Whatman No.1 kâğıdı ile süzüldü. Ekstraktlar falkon tüplerine konuldu ve kullanılana kadar $-20^{\circ} \mathrm{C}$ 'de saklandı. Bu bitkilerin $1 \mathrm{mg} / \mathrm{mL}$ stok su ekstraktları hazırlanmış ve her bir ekstraktın serum TAS ve TOS ile CAT, MPO ve PON1 enzim aktiviteleri üzerine etki dereceleri saptanmıştır.

Çalışma için Harran Üniversitesi Klinik Araştırmalar Etik Kurulunun 30.12.2019 tarih ve 08 sayılı kararı ile izin alınmıştır.

Çalışma için serum numuneleri, Harran Üniversitesi Araştırma ve Uygulama Hastanesine müracaat eden 1-16 yaş aralığındaki hastalardan, rutin tetkikleri tamamlandıktan sonra arta kalan serum numunelerinden laboratuvar tetkikleri açısından anormal bir bulguya rastlanmamış olanlardan 50 adedi alınarak serum havuzu oluşturulmak suretiyle hazırlanmıştır. Hazırlanan bitki ekstraktları serum numunelerine belli oranda eklenerek nihai konsantrasyon 60 $\mu \mathrm{g} / \mathrm{mL}$ olacak şekilde uygulanmıştır. Çalışma, aynı serum havuzu numunelerine bitki ekstraktlarının uygulanması öncesi ve sonrası parametrelerin karşılaştıııması suretiyle 
yapılmıştır. Uygulama öncesi ve sonrası numunelerin absorbansları otoanalizörde (Architect C16000, Abbott) ölçülmüştür.

MPO aktivitesi, Bradley vd'nin tariflediği yöntemin bir modifikasyonuyla ölçülmüştür (26). Prensip olarak MPO $\mathrm{H}_{2} \mathrm{O}_{2}$ 'yi indirger. Oluşan yeni kompleks o-dianisidin ile reaksiyona girer ve 460 nm'de en yüksek absorbans veren sarımsı turuncu renkte bir ürün oluşturur. Sonuçlar IU/L olarak ifade edilmiştir.

PON1 aktivitesi, Eckerson vd.'nin tariflediği yöntemin bir modifikasyonu ile ölçülmüştür (27). Prensip olarak PON1, substratı olan paraoxon ve kofaktörü kalsiyumun bulunduğu bazik ortam içerisinde $p$-nitrofenol oluşturur. P-nitrofenolün molar emilimi 18,290 M-1 cm-1 olup en yüksek absorbansı 412 nm'dedir. Sonuçlar IU/L olarak ifade edilmiştir.

CAT aktivitesi, Goth'in tariflediği yöntemin bir modifikasyonu ile ölçülmüştür (28). Prensip olarak numunede bulunan CAT, su ve oksijen üretmek üzere hidrojen peroksit ile reaksiyona girer. Tüketilmemiş olan hidrojen peroksit sonradan eklenen amonyum molibdat ile sarı renkli bir kompleks oluşturur. Numunelerin absorbansı 412 nm'de ölçülmüş olup, sonuçlar kU/L olarak ifade edilmiştir.

TAS, Erel'nin tariflediği yönteme göre ölçülmüştür (29). Bu yönteme göre, numunedeki antioksidanlar koyu mavi-yeşil renkli $A B T S$ radikalini, renksiz indirgenmiş $A B T S$ formuna dönüştürür. 660 nm'deki absorbans değişikliği, numunenin toplam antioksidan seviyesi ile orantılıdır. Yöntem, troloks çözeltisi ile kalibre edilmiş ve sonuçlar mmol troloks eşdeğeri/L olarak ifade edilmiştir.

TOS, Erel'nin tariflediği yönteme göre ölçülmüştür (30). Bu yönteme göre, numunede bulunan oksidanlar, ferröz iyon şelatlayıcı kompleksi ferrik iyona okside eder. Ferrik iyon, asidik bir ortamda kromojen (xylenol orange) ile renkli bir kompleks oluşturur ve bu renk yoğunluğu, numunedeki toplam oksidan molekül yoğunluğuyla orantıııır. Yönem, $\mathrm{H}_{2} \mathrm{O}_{2}$ çözeltisi ile kalibre edilmiş ve sonuçlar $\mu \mathrm{mol} \mathrm{H}_{2} \mathrm{O}_{2}$ eşdeğeri/L olarak ifade edilmiştir.

\section{Istatistiksel Analiz}

İstatistiksel hesaplamalar Sosyal Bilimler için İstatistik Paketi (SPSS) sürüm 22 kullanılarak yapıldı. Öıçümler 3 kez tekrarlandı ve sonuçlar ortalama değer \pm standart sapma (Ortalama \pm SD) olarak ifade edildi. İstatistiksel değerlendirme Paired Samples Test kullanılarak yapıldı. Olasılık değeri $p<0.05$ olan farklar istatistiksel olarak anlamlı kabul edildi.

\section{Bulgular}

Kontrol serumunda CAT $(23,233 \pm 1,665 \mathrm{kU} / \mathrm{L})$, MPO $(103,483 \pm 4,048 \mathrm{U} / \mathrm{L})$ ve PON1 $(24,833 \pm 1,404 \mathrm{U} / \mathrm{L})$ aktivitesi ile TAS $(1,223 \pm 0,080 \mathrm{mmol}$ Troloks Eqv/L) ve TOS $\left(6,350 \pm 0,481 \mu \mathrm{mol} \mathrm{H}_{2} \mathrm{O}_{2}\right.$ Eqv/L) düzeyleri kantitatif olarak saptanmıştır. (Tablo-1).

Pelin otu CAT $(19,633 \pm 1,205 \mathrm{kU} / \mathrm{L} ; \mathrm{p}<0.05)$, MPO
$(96,026 \pm 2,783 \mathrm{U} / \mathrm{L} ; \mathrm{p}<0.05)$ ve PON1 $(17,033 \pm 1,361 \mathrm{U} / \mathrm{L}$; $p<0.01)$ aktivitelerini inhibe ederken, TAS $(1,243 \pm 0,100$ $\mathrm{mmol}$ Troloks Eqv/L; $p>0.05)$ ve TOS $(6,010 \pm 0,480 \mu \mathrm{mol}$ $\mathrm{H}_{2} \mathrm{O}_{2}$ Eqv/L; $p>0.05$ ) düzeylerini istatistiksel olarak etkilememiştir (Tablo-1).

Tablo 1. Bazı bitki ekstraktlarının ( $60 \mu \mathrm{g} / \mathrm{mL}$ ) önemli metabolik enzimler ve TAS / TOS üzerindeki etkisi

\begin{tabular}{|c|c|c|c|c|c|}
\hline $\begin{array}{l}\text { Tıbbi } \\
\text { Bitkiler }\end{array}$ & $\begin{array}{l}\text { CAT } \\
\text { (kU/L) }\end{array}$ & $\begin{array}{l}\text { MPO } \\
\text { (U/L) }\end{array}$ & $\begin{array}{l}\text { PON1 } \\
\text { (U/L) }\end{array}$ & $\begin{array}{l}\text { TAS (mmol } \\
\text { Troloks } \\
\text { Eqv/L) }\end{array}$ & $\begin{array}{l}\text { TOS ( } \mu \mathrm{mol} \\
\mathrm{H}_{2} \mathrm{O}_{2} \text { Eqv/L) }\end{array}$ \\
\hline $\begin{array}{l}\text { Kontrol } \\
\text { (Uygulama } \\
\text { öncesi) }\end{array}$ & $\begin{array}{l}23,233 \pm \\
1,665\end{array}$ & $\begin{array}{l}103,483 \\
\pm 4,048\end{array}$ & $\begin{array}{l}24,833 \pm \\
1,404\end{array}$ & $\begin{array}{l}1,223 \pm \\
0,080\end{array}$ & $\begin{array}{c}6,350 \pm \\
0,481\end{array}$ \\
\hline $\begin{array}{l}\text { Artemisia } \\
\text { absinthium } \\
\text { (Pelin otu) } \\
\text { Ferula }\end{array}$ & $\begin{array}{l}19,633 \pm \\
1,205^{*}\end{array}$ & $\begin{array}{l}96,026 \pm \\
2,783^{*}\end{array}$ & $\begin{array}{l}17,033 \pm \\
1,361^{* *}\end{array}$ & $\begin{array}{l}1,243 \pm \\
0,100\end{array}$ & $\begin{array}{l}6,010 \pm \\
0,480\end{array}$ \\
\hline Meifolia & $20,320 \pm$ & $90,060 \pm$ & $22,200 \pm$ & $1,206 \pm$ & $6,173 \pm$ \\
\hline $\begin{array}{l}\text { (Çakşır } \\
\text { otu) } \\
\text { Achillea }\end{array}$ & $1,217^{\star}$ & 3,880 ** & $1,442^{*}$ & 0,092 & 0,384 \\
\hline millefolium & $19,033 \pm$ & $94,980 \pm$ & $21,686 \pm$ & $1,383 \pm$ & $5,720 \pm$ \\
\hline $\begin{array}{l}\text { (Civanper- } \\
\text { çemi) } \\
\text { Equisetum }\end{array}$ & $1,222^{*}$ & $4,296^{*}$ & $1,160^{*}$ & $0,081^{* *}$ & $0,491^{*}$ \\
\hline $\begin{array}{l}\text { arvense } \\
\text { (Tarla at- } \\
\text { kuyruğu) } \\
\text { Hypericum }\end{array}$ & $\begin{array}{l}21,013 \pm \\
1,397\end{array}$ & $\begin{array}{l}89,370 \pm \\
4,282^{\star *}\end{array}$ & $\begin{array}{l}23,176 \pm \\
1,472\end{array}$ & $\begin{array}{l}1,203 \pm \\
0,092\end{array}$ & $\begin{array}{l}6,123 \pm \\
0,422\end{array}$ \\
\hline $\begin{array}{l}\text { perforatum } \\
\text { (Sarı kan- } \\
\text { taron) }\end{array}$ & $\begin{array}{l}18,693 \pm \\
1,214^{*}\end{array}$ & $\begin{array}{l}88,826 \pm \\
4,048^{\star *}\end{array}$ & $\begin{array}{l}21,516 \pm \\
1,351^{*}\end{array}$ & $\begin{array}{l}1,333 \pm \\
0,081 *\end{array}$ & $\begin{array}{l}5,973 \pm \\
0,384^{\star}\end{array}$ \\
\hline
\end{tabular}

Bitki ekstraktlarının (60 $\mu \mathrm{g} / \mathrm{mL}$ 'de) parametreler üzerindeki etkisi, kontrol grubuna (uygulama öncesi) kıyasla.

${ }^{* * *} p<0.001{ }^{* *} p<0.01,{ }^{*} p<0.05$ olarak tanımlandı.

Çakşır otu da Pelin otu ile benzer şekilde CAT $(20,320 \pm 1,217 \mathrm{kU} / \mathrm{L} ; \mathrm{p}<0.05), \mathrm{MPO}(90,060 \pm 3,880 \mathrm{U} / \mathrm{L} ; \mathrm{p}$ $<0.05)$ ve PON1 $(22,200 \pm 1,442 \mathrm{U} / \mathrm{L} ; \mathrm{p}<0.05)$ aktivitelerini inhibe ederken, TAS $(1,206 \pm 0,092 \mathrm{mmol}$ Troloks Eqv/L; $p$ $>0.05)$ ve TOS $\left(6,173 \pm 0,384 \mu \mathrm{mol} \mathrm{H}_{2} \mathrm{O}_{2}\right.$ Eqv/L; $\left.p>0.05\right)$ düzeylerini istatistiksel olarak etkilememiştir. Ancak farklı olarak PON1'e kıyasla MPO aktivitesini daha çok inhibe etmiştir (Tablo-1).

Civanperçemi CAT $(19,033 \pm 1,222 \mathrm{kU} / \mathrm{L} ; \mathrm{p}<0.05)$, MPO $(94,980 \pm 4,296 \mathrm{U} / \mathrm{L} ; \mathrm{p}<0.05)$ ve PON1 $(21,686 \pm 1,160 \mathrm{U} / \mathrm{L}$; p <0.05) aktivitelerini inhibe etmekle birlikte TAS $(1,383 \pm 0,081 \mathrm{mmol}$ Troloks Eqv/L; $p<0.01)$ düzeyini artırıp, TOS $\left(5,720 \pm 0,491 \mu \mathrm{mol} \mathrm{H}_{2} \mathrm{O}_{2}\right.$ Eqv/L; $\left.p<0.05\right)$ düzeyini azaltmıştır (Tablo-1).

Sarı kantaron da civanperçemi gibi CAT $(18,693 \pm 1,214$ $\mathrm{kU} / \mathrm{L} ; p<0.05)$, MPO $(88,826 \pm 4,048 \mathrm{U} / \mathrm{L} ; p<0.01)$ ve PON1 (21,516 $\pm 1,351 \mathrm{U} / \mathrm{L} ; \mathrm{p}<0.05)$ aktivitelerini inhibe ederken; TAS $(1,333 \pm 0,081 \mathrm{mmol}$ Troloks Eqv/L; $p<0.05)$ düzeyini artırıp TOS $\left(5,973 \pm 0,384 \mu \mathrm{mol}_{2} \mathrm{O}_{2}\right.$ Eqv/L; $p$ $<0.05)$ düzeyini azaltmıştır (Tablo-1).

Tarla atkuyruğu ise CAT $(21,013 \pm 1,397 \mathrm{kU} / \mathrm{L} ; p>0.05)$ ve PON1 $(23,176 \pm 1,472 \mathrm{U} / \mathrm{L} ; \mathrm{p}>0.05)$ aktiviteleri ile TAS $(1,203 \pm 0,092 \mathrm{mmol}$ Troloks Eqv/L; $p>0.05)$ ve TOS 
$\left(6,123 \pm 0,422 \mu \mathrm{mol} \mathrm{H}_{2} \mathrm{O}_{2}\right.$ Eqv/L; $\left.p>0.05\right)$ düzeylerini istatistiksel olarak etkilemezken, MPO $(89,370 \pm 4,282 \mathrm{U} / \mathrm{L} ; \mathrm{p}$ $<0.01)$ aktivitesini etkili bir şekilde inhbe etmiştir (Tablo-1). Bütün bitki ekstraktlarının MPO üzerine istatistiksel olarak belirgin derecede inhibe edici etkilerinin olduğu ve en yüksek inhibisyonun ise sarı kantaronda olduğu görülmüştür $(P<0.01)$.

Şekil-1'deki grafikte gösterildiği gibi çakşır otu ve tarla atkuyruğunun konsantrasyon artışına bağlı olarak MPO enzim aktivitesinin azaldığı görülmektedir ( $\mathrm{y}=-0,1867 \mathrm{x}+$ 103,66

$\left.R^{2}=0,9837 ; y=-0,1581 x+102,9 R^{2}=0,9692\right)$.

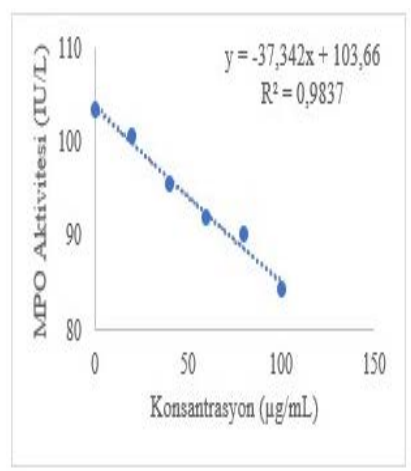

a

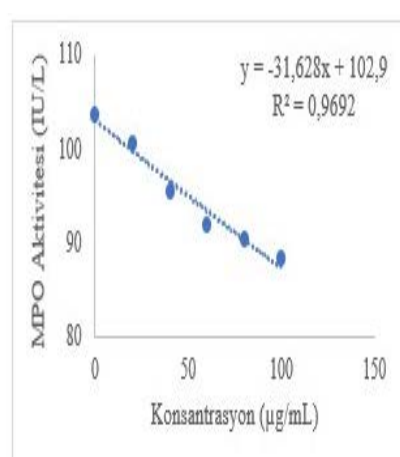

b
Şekil 1. Çakşır otu (a) ve tarla at kuyruğunun (b) farklı konsantrasyonlardaki su ekstraktının MPO enzim üzerine etkisi

\section{Tartışma}

Bitkiler tarih öncesine dayanan birçok hastalığın tedavisi için kullanılır ve tüm insanlar bu eski geleneğe sahiptir. Antioksidan, antimikrobiyal, antifungal, antitümöral ve antienflamatuar aktiviteleri nedeniyle doğal ürünler uzun süredir kullanılmaktadır. Günümüzde bitki özleri insanlar arasında sağlığı koruyucu maddeler olarak tüketilmektedir. Bu oran dünya nüfusunun neredeyse $\% 80$ 'inden fazladır (31). Bitkilerin çoğu fenolik bileşikler, benzofenonlar, ksantenler, biyoflavonoid, flavonoid, terpenler ve antrakinonlar, siyanatlar, oksalatlar, tanenler ve saponinler gibi bazı metabolitler bakımından zengindir (32).

Yüksek yoğunluklu lipoprotein (HDL) kardiyoprotektiftir ve seviyeleri kardiyovasküler hastalık riski ile ters orantılıdır. Bununla birlikte, biyolojik karmaşıklığı nedeniyle, çalışmalar yakın zamanda sadece HDL kolesterol (HDL-C) konsantrasyonunun her zaman HDL fonksiyonunu yansitmayabileceğini ve önemli klinik faydaları olmayabileceğini önermektedir; daha ziyade HDL proteinleri, özellikle enzim bileşenleri daha önemli olabilir $(33,34)$. Çalışmalara göre, HDL proteomundaki değişiklikler HDL fonksiyonunu etkiler ve ayrıca koroner arter hastalığı riski ile ilişkilidir ve protein bileşenleri terapötik bir hedef olabilir (35).

PON1 esas olarak karaciğer tarafından sentezlenen ve kana salınan ve HDL partiküllerine fiziksel olarak bağlanan bir esteraz/laktonazdır. Bu çok fonksiyonlu enzim, oksitlenmiş fosfolipidleri parçalayabilir ve laktonları lipoproteinlerden hidrolize edebilir $(36,37)$. HDL'nin, özellikle LDL'nin oksidasyonunu azaltıcı etkisinin bulunduğu, bununla birlikte HDL'nin bu antioksidan özelliğinin içerdiği bileşenler arasında en çok PON1 ile ilişkili olduğu ortaya konulmuştur (38). Bir başka çalışmada insan PON1 transgenik farelerinde, plazma kolesterol düzeyi değişmediği halde aterosklerotik lezyonların önemli ölçüde azaldığı ve bu farelerden alınan HDL'nin LDL oksidasyonunu daha etkili bir şekilde önlediği gösterilmiştir (39). Yine koroner arter hastalığı olanlarda, azalmış PON1 aktivitesine bağlı olarak ortaya çıkan endotelyal HDL'de yüksek malondialdehit oluşumu saptandığı ve bunun endotelyal HDL işlevselliği üzerinde olumsuz bir etkiye sahip olabileceği belirtilmiştir (40).

PON1'den farklı olarak MPO, lipoproteinlerin oksidatif modifikasyonunda rol oynar. Bu enzim, nötrofiller, monositler ve bazı doku makrofajlarında (aterosklerotik plaklarda olduğu gibi) yüksek seviyelerde eksprese edilen bir hemoprotein olup reaktif oksidanların üretimini katalize eder (41, 42). Reaktif oksidanlar konağın savunması için önemli olmakla birlikte, aşırı üretimi iltihaplı dokuya zararlı olabilir ve ayrıca vasküler inflamasyona ve plak oluşumuna katkıda bulunduğuna inanılmaktadır $(7,43)$.

PON1 ve MPO işlevinin modifikasyonu HDL işlevselliğine önemli ölçüde katkıda bulunur ve bu da kardiyovasküler hastalıklarda rol oynar $(40,44)$. MPO, HDL disfonksiyonu ve artmış bir kardiyovasküler hastalık riskine yol açan potansiyel bir mekanizma olabilecek PON1 aktivitesinin negatif bir belirleyicisidir (9). PON1, HDL lipit yüzeyi üzerindeki MPO'ya bağlanır ve MPO tarafından gerçekleştirilen lipit peroksidasyonunun başlangıcının inhibe olmasına yardımcı olur (45).

Yapılan bir çalışmada, antienflamatuar aktivite gösteren üç Hypericum türünün insan polimorfonükleer lökosit MPO aktivitesi üzerindeki in vitro etkisi araştııımış. Bulgularımızla tutarlı olarak her bir Hypericum türü ekstraktının, insan lökosit MPO'sunun peroksidatif aktivitesini konsantrasyona bağı bir şekilde azalttığı bulunmuştur. Bu türlerin antienflamatuar aktivitesinin, MPO inhibisyonu ile ilişkili olabileceği vurgulanmıştır (46).

Yapılan bir çalışmada pelin otunun flavonoid, fenolik ve tanen içeriği bakımından zengin olduğu bildirilmiştir. Bu zengin içeriğinden dolayı serbest radikal giderme potansiyeline sahip olabileceği ifade edilmiştir (47). Ters faz HPLC kullanılarak çakşır otunun içeriğinde rezorsinol, ferulik ve siringirik asit ile kumarin gibi fenolik bileşikler tanımlanmıştır. İçeriğindeki bu fenolik bileşiklerden dolayı antioksidan aktiviteye sahip olduğu bildirilmiştir (21). Yapılan birçok çaIışmada tıbbi bitkilerin fenolik içerik bakımından zengin olduğu ve antioksidan aktivitelere sahip olduğu vurgulanmıştır. Bu bitkiler antioksidan aktivitelerinin bir sonucu olarak da anti-enflamatuar, anti-kanserojen ve antiaterosklerotik gibi çeşitli biyolojik etkilere sahiptir (15). 
Çalışmamızda kullanılan bu tıbbi bitkilerin antioksidan enzimler üzerine etkisinin fenolik içeriğinden dolayı olabileceği söylenebilir..

\section{Sonuç}

Sonuç olarak, geleneksel olarak kullanılan tıbbi bitkilerden çakşır otu ve tarla atkuyruğu bitki ekstraktları in vitro olarak MPO üzerine inhibisyon etkisi gösterirken, PON1 üzerine ise zayıf inhibisyon etkisi göstermiştir. Bu bitkilerin in vivo etkinliği ortaya konulabilirse HDL-LDL metabolizması üzerinde düzenleyici etki ile kardiyovasküler hastalıklar üzerine tedavi edici etkisinin olabileceği ve ateroskleroz gibi hastalıklarda intravasküler lipit peroksidasyonu sonucu meydana gelen plak oluşumunu inhibe edebileceği ve vasküler fonksiyonları iyileştirebileceği söylenebilir.

Çıkar Çatışması: Yazarlar aralarında çıkar çatışması olmadığını beyan eder.

Finansal Destek: Finansal destek alınmamıştır.

Etik Onam: Bu çalışma için Harran Üniversitesi Klinik Araştırmalar Etik Kurulunun 30.12.2019 tarih ve 08 sayılı kararı ile izin alınmıştır.

\section{Kaynaklar}

1. Devasagayam TP, Tilak JC, Boloor KK, Sane KS, Ghaskadbi SS, Lele RD. Free radicals and antioxidants in human health: current status and future prospects. J Assoc Physicians India. 2004;52:794-804.

2. Stocker R, Keaney JF, Jr. Role of oxidative modifications in atherosclerosis. Physiol Rev. 2004;84(4):1381-478.

3. Schwenke DC. Antioxidants, dietary fat saturation, lipoprotein oxidation and atherogenesis. Nutrition. 1996;12(5):377-9.

4. Serdar Z, Aslan K, Dirican M, Sarandol E, Yesilbursa D, Serdar A Lipid and protein oxidation and antioxidant status in patients with angiographically proven coronary artery disease. Clin Biochem. 2006;39(8):794-803.

5. Işık M, Demir Y, Kırıcı M, Demir R, Şimşek F, Beydemir Ş. Changes in the anti-oxidant system in adult epilepsy patients receiving anti-epileptic drugs. Archives of physiology and biochemistry. 2015;121(3):97102.

6. Mates JM, Perez-Gomez C, Nunez de Castro I. Antioxidant enzymes and human diseases. Clin Biochem. 1999;32(8):595-603.

7.Variij A, Shokri Y, Fallahpour S, Zargari M, Bagheri B, Abediankenari $\mathrm{S}$, et al. The combined utility of myeloperoxidase (MPO) and paraoxonase 1 (PON1) as two important HDL-associated enzymes in coronary artery disease: Which has a stronger predictive role? Atherosclerosis. 2019;280:7-13.

8. Khine HW, Teiber JF, Haley RW, Khera A, Ayers CR, Rohatgi A. Association of the serum myeloperoxidase/high-density lipoprotein particle ratio and incident cardiovascular events in a multi-ethnic population: $\mathrm{Ob}$ servations from the Dallas Heart Study. Atherosclerosis. 2017;263:15662.

9. Jornayvaz FR, Brulhart-Meynet MC, James RW. Myeloperoxidase and paraoxonase-1 in type 2 diabetic patients. Nutr Metab Cardiovasc Dis. 2009;19(9):613-9.

10. Sun H, Shen J, Liu T, Tan Y, Tian D, Luo T, et al. Heat shock protein 65 promotes atherosclerosis through impairing the properties of high density lipoprotein. Atherosclerosis. 2014;237(2):853-61.

11. Nussbaum C, Klinke A, Adam M, Baldus S, Sperandio M. Myelope- roxidase: a leukocyte-derived protagonist of inflammation and cardiovascular disease. Antioxid Redox Signal. 2013;18(6):692-713.

12. Palinkas Z, Furtmuller PG, Nagy A, Jakopitsch C, Pirker KF, Magierowski $\mathrm{M}$, et al. Interactions of hydrogen sulfide with myeloperoxidase. Br J Pharmacol. 2015;172(6):1516-32.

13. van Dalen CJ, Whitehouse MW, Winterbourn CC, Kettle AJ. Thiocyanate and chloride as competing substrates for myeloperoxidase. Biochem J. 1997;327 ( Pt 2):487-92.

14. Gerber M, Boutron-Ruault MC, Hercberg S, Riboli E, Scalbert A, Siess MH. [Food and cancer: state of the art about the protective effect of fruits and vegetables]. Bulletin du cancer. 2002;89(3):293-312.

15. Krishnaiah D, Sarbatly R, Nithyanandam R. A review of the antioxidant potential of medicinal plant species. Food Bioprod Process. 2011;89(3):217-33.

16. Knekt $P$, Jarvinen $R$, Reunanen $A$, Maatela J. Flavonoid intake and coronary mortality in Finland: a cohort study. BMJ (Clinical research ed). 1996;312(7029):478-81.

17. Tohma H, Isik M, Korkmaz M, Bursal E, Gulcin I, Koksal E. Determination of antioxidant properties of Gypsophila bitlisensis Bark. International journal of pharmacology. 2015;100(4):366-371.

18. Scartezzini P, Speroni E. Review on some plants of Indian traditional medicine with antioxidant activity. J Ethnopharmacol. 2000;71(1-2):2343.

19. Matkowski A. Plant in vitro culture for the production of antioxidants-a review. Biotechnol Adv. 2008;26(6):548-60.

20. Abad MJ, Bedoya LM, Apaza L, Bermejo P. The Artemisia L. genus: a review of bioactive essential oils. Molecules. 2012;17(3):2542-66.

21. Rahali FZ, Kefi S, Bettaieb Rebey I, Hamdaoui G, Tabart J, Kevers $C$, et al. Phytochemical composition and antioxidant activities of different aerial parts extracts of Ferula communis L. Plant Biosystems-An International Journal Dealing with all Aspects of Plant Biology. 2019;153(2):213-21.

22. Montanari T, de Carvalho JE, Dolder H. Antispermatogenic effect of Achillea millefolium L. in mice. Contraception. 1998;58(5):309-13.

23. Oh H, Kim D-H, Cho J-H, Kim Y-C. Hepatoprotective and free radical scavenging activities of phenolic petrosins and flavonoids isolated from Equisetum arvense. J Ethnopharmacol. 2004;95(2-3):421-4.

24. Pabuçcuoğlu A, Konyalıoğlu S, Baş M, Meral GE. The in vitro effects of Hypericum species on human leukocyte myeloperoxidase activity. J Ethnopharmacol. 2003;87(1):89-92.

25. Işık M, Dikici E, Tohma H, Köksal E. Antioxidant activity and total phenolic/flavonoid contents of phlomis pungens L. 2017.

26. Bradley PP, Priebat DA, Christensen RD, Rothstein G. Measurement of cutaneous inflammation: estimation of neutrophil content with an enzyme marker. J Invest Dermatol. 1982;78(3):206-9.

27. Eckerson HW, Wyte CM, La Du BN. The human serum paraoxonase/arylesterase polymorphism. Am J Hum Genet. 1983;35(6):1126-38.

28. Goth $L$. A simple method for determination of serum catalase activity and revision of reference range. Clin Chim Acta. 1991;196(2-3):143-51. 29. Erel $O$. A novel automated direct measurement method for total antioxidant capacity using a new generation, more stable ABTS radical cation. Clin Biochem. 2004;37(4):277-85.

30. Erel O. A new automated colorimetric method for measuring total oxidant status. Clin Biochem. 2005;38(12):1103-11.

31. Sahin H, Can Z, Yildiz O, Kolayli S, Innocenti A, Scozzafava G, et al. Inhibition of carbonic anhydrase isozymes I and II with natural products extracted from plants, mushrooms and honey. J Enzyme Inhib Med Chem. 2012;27(3):395-402.

32. Kaya ED, Ergun B, Demir Y, Alım Z, Beydemir Ş. The In Vitro Impacts of Some Plant Extracts on Carbonic Anhydrase I, II and Paraoxonase-1. Hacettepe J Biol Chem. 2019;47(1).

33. Papageorgiou N, Tousoulis $\mathrm{D}$. Is HDL a prognostic biomarker for coronary atherosclerosis? Int J Cardiol. 2014;174(3):465-7.

34. Rosenson RS, Brewer HB, Jr., Ansell B, Barter P, Chapman MJ, Heinecke JW, et al. Translation of high-density lipoprotein function into 
clinical practice: current prospects and future challenges. Circulation. 2013;128(11):1256-67.

35. Wang G, Mathew AV, Yu H, Li L, He L, Gao W, et al. Myeloperoxidase mediated $\mathrm{HDL}$ oxidation and $\mathrm{HDL}$ proteome changes do not contribute to dysfunctional $\mathrm{HDL}$ in Chinese subjects with coronary artery disease. PloS one. 2018;13(3):e0193782.

36. Forstermann U. Oxidative stress in vascular disease: causes, defense mechanisms and potential therapies. Nat Clin Pract Cardiovasc Med. 2008;5(6):338-49.

37. Mahrooz A, Hashemi-Soteh MB, Heydari M, Boorank R, Ramazani F, Mahmoudi A, et al. Paraoxonase 1 (PON1)-L55M among common variants in the coding region of the paraoxonase gene family may contribute to the glycemic control in type 2 diabetes. Clin Chim Acta. 2018;484:40-6.

38. Srivastava RAK. Dysfunctional HDL in diabetes mellitus and its role in the pathogenesis of cardiovascular disease. Mol Cell Biochem. 2018;440(1-2):167-87.

39. Tward A, Xia YR, Wang XP, Shi YS, Park C, Castellani LW, et al. Decreased atherosclerotic lesion formation in human serum paraoxonase transgenic mice. Circulation. 2002;106(4):484-90.

40. Annema W, von Eckardstein A. Dysfunctional high-density lipoproteins in coronary heart disease: implications for diagnostics and therapy. Transl Res. 2016;173:30-57.

41. Tietge UJF. The impact of myeloperoxidase on HDL function in myocardial infarction. Curr Opin Endocrinol Diabetes Obes. 2018;25(2):13742.

42. Zhang R, Brennan ML, Fu X, Aviles RJ, Pearce GL, Penn MS, et al. Association between myeloperoxidase levels and risk of coronary artery disease. Jama. 2001;286(17):2136-42.

43. Schaub N, Reichlin T, Meune C, Twerenbold R, Haaf P, Hochholzer $\mathrm{W}$, et al. Markers of plaque instability in the early diagnosis and risk stratification of acute myocardial infarction. Clin Chem. 2012;58(1):24656.

44. Huang Y, DiDonato JA, Levison BS, Schmitt D, Li L, Wu Y, et al. An abundant dysfunctional apolipoprotein A1 in human atheroma. Nat Med. 2014;20(2):193-203

45. Gu X, Huang Y, Levison BS, Gerstenecker G, DiDonato AJ, Hazen LB, et al. Identification of Critical Paraoxonase 1 Residues Involved in High Density Lipoprotein Interaction. J Biol Chem. 2016;291(4):1890904.

46. Pabuccuoglu A, Konyalioglu S, Bas M, Meral GE. The in vitro effects of Hypericum species on human leukocyte myeloperoxidase activity. J Ethnopharmacol. 2003;87(1):89-92.

47. Singh R, Verma PK, Singh G. Total phenolic, flavonoids and tannin contents in different extracts of Artemisia absinthium. Journal of Complementary Medicine Research. 2012;1(2):101-4. 